\title{
New records of heterostigmatic mites (Acari: Heterostimatina) from dry rice cultivation of Gorgan, northern Iran
}

\author{
Vahid Rahiminejad \\ Department of Plant Protection, Faculty of Plant Production, Gorgan University of Agricultural Sciences and Natural \\ Resources, Gorgan, Iran. \\ \vahidrahiminejad@gau.ac.ir; (iD https://orcid.org/0000-0002-8878-3614 \\ Mohsen Yazdanian \\ Department of Plant Protection, Faculty of Plant Production, Gorgan University of Agricultural Sciences and Natural \\ Resources, Gorgan, Iran. \\ \mohsenyazdanian@gau.ac.ir; (iD https://orcid.org/0000-0001-7321-7997

\section{Safieh Zeitounli} \\ Department of Plant Protection, Faculty of Plant Production, Gorgan University of Agricultural Sciences and Natural \\ Resources, Gorgan, Iran. \\ \safie.zeytuonli73@gmail.com; (DiD https://orcid.org/0000-0002-6479-9355 \\ Received: \\ 30 October, 2021 \\ Accepted: \\ 23 December, 2021 \\ Published: \\ 05 January, 2022 \\ Subject Editor: \\ Alihan Katlav

\begin{abstract}
Gorgan, is a city in northern Iran where its moderate and humid climate and fertile soil provides an appropriate condition for various arthropods and crops. Although, species diversity is relatively lower in agricultural systems than pristine ecosystems, several soil mite populations are successfully adapted to both tilled and untilled lands. Following a faunistic study of heterostigmatic mites (Acari: Prostigmata: Heterostigmatina) in dry rice cultivations in some areas of Gorgan, eight species from six genera of five families were collected and identified. For the first time we report six species for Iranian arthropod fauna as well as several new host associations. Finally, we reviewed the world distribution of the recovered mites and further provided a key to
\end{abstract} \\ Heterostigmatina of dry rice cultivations in Gorgan city. \\ Key words: Mite, insect, soil, crop, phoresy, Iran
}

Citation: Rahiminejad, V., Yazdanian, M. \& Zeitounli, S. (2022) New records of heterostigmatic mites (Acari: Heterostimatina) from dry rice cultivation of Gorgan, northern Iran. Journal of Insect Biodiversity and Systematics, 8 (1), 121-129.

\section{INTRODUCTION}

Rice is cultivated in various systems with diverse ecosystems in Iran and is an important crop in food security of millions of people. Gorgan, a city located along the southern Caspian Sea shoreline and north of the Alborz Mountains, represents moderate and humid climate and fertile soils, and is a key region for rice cultivation in Iran (Jaiswal et al., 2016; Razzaghi et al., 2020; Rahiminejad \& Hajiqanbar, 2020). Reduction in precipitation in the last few decades has modified the rice cultivation system from water logging (paddy-soil) into dry system in some parts of northern Iran (Ghorbaniminaei et al., 2019; Razzaghi et al., 2020). Since ecosystems are highly complex with network of interdependencies and interactions among different species and their habitats, changing in climate factors affect natural flora and fauna. Therefore, mites with important role in this intricate ecological system are highly affected by ecological dynamics (Okabe et al., 2012; Gwiazdowicz, 2021). Heterostigmatic mites (Acari: 
Prostigmata) are classified in eight Superfamilies and include more than 2000 described species (Walter et al., 2009; Zhang et al., 2011). It seems fungivory and herbivory are the most feeding strategies in the subclass of mites. The also exhibit various symbiotic associations with other animals (especially insects) such as kleptoparasitism, parasitism, parasitoidism, predatory and phoresy, with the latter being probably derived from the free-living fungivorous ancestors (Kaliszewski et al., 1995; Walter et al., 2009).

Possibly the new cultivation method would prepare more appropriate conditions for mites, due to their terrestrial locomotion behaviors (Walter et al., 2009). Since mite fauna in dry rice cultivations and their vicinities have not been studied so far, and given that several heterostigmatic species such as Steneotorsonemus spinki Smiley, are pest of rice, (Kayal et al., 2021), this study has been conducted to determine the heterostigmatic mite fauna in dry rice cultivations of Gorgan.

\section{MATERIAL AND METHODS}

The mites were collected using three sampling methods. Rice sheaths were collected directly from the field and examined under stereomicroscope. Also, soil dwelling mites were extracted from collected soil samples using Berlese funnels. Eventually, for phoretic mites, the host insect specimens were captured using light trap, in the dry rice cultivation in vicinity of Gorgan. Mite specimens were collected from leaves and sheaths of rice, separated from soil particles or extracted from their host insects under a stereomicroscope (Olympus ${ }^{\circledR}$ SZ, Tokyo, Japan). Collected specimens were transferred to a clearing solution comprising of a mixture of lactophenol and Nesbitt's fluids (1:1 ratio), and subsequently mounted in Hoyer's medium. Microscopic slides were studied using an Olympus ${ }^{\circledR}$ BX51 phase-contrast microscope. The taxonomical hierarchy follows that of Kaliszewski et al. (1995) and Khaustov (2004). All obtained specimens were adult female and collected by the first and third authors. All the materials are deposited in the Arthropods Collection, Acari Section, Department of Plant Protection, Faculty of Plant Production, Gorgan University of Agricultural Sciences and Natural Resources, Gorgan, Iran.

\section{NOTES ON THE RESULTS}

Mites are given in alphabetical order based on superfamilies followed by families, genera and species. World distribution - Country(ies), host(s) [as given in source publication], source publication(s). Material examined - All available data about species, host(s), sampling method(s) and location(s). Remarks - Any relevant information [new record for fauna of Iran and/or new host record(s)].

\section{RESULTS}

\section{Cohort Heterostigmata}

Superfamily Dolichocyboidea Mahunka, 1970

Family Dolichocybidae Mahunka, 1970

Genus Dolichomotes Smiley, 1967

Type species: Dolichomotes navei Smiley, 1967, by original designation.

\section{Dolichomotes crossi Rack, 1973}

World distribution. United States - 21 females were collected under bark of walnut trees (Juglans sp.) (Rack, 1973).

Material examined. 1 우, Iran, Golestan province, Gorgan, Nodijeh village $\left(36.49^{\circ} \mathrm{N}, 54.16^{\circ} \mathrm{E}, 28 \mathrm{~m}\right.$ a.s.1.), extracted from soil, litter and rotten leaves sample under Oak trees (Quercus sp.) in vicinity of dry rice cultivation, 1.vi.2020, leg.: V. Rahiminejhad. 
Remarks. Dolichomotes crossi has only been recorded from Nearctic region (Rack 1973), so, this is the first record of the species from Palaearctic region. Previously, only one species of this genus, $D$. sinuspersicus has been recorded from Iran, Hormozgan province (Mortazavi et al., 2015).

\section{Superfamily Pygmephoroidea Cross, 1965}

Family Pygmephoridae Cross, 1965

Genus Pediculaster Vitzthum, 1931

Type species: Pygmephorus mesembrinae Canestrini, 1881, by original designation.

\section{Pediculaster dudichi Mahunka, 1970}

World distribution. Hungary-phoretomorphic females were collected from soil samples (Mahunka, 1970).

Material examined. 3 우, Iran, Golestan province, Gorgan, Nodijeh village $\left(36.90^{\circ} \mathrm{N}, 54.52^{\circ} \mathrm{E}, 97 \mathrm{~m}\right.$ a.s.l.), extracted from a soil sample in dry rice cultivation, 19.vii.2020; 2우, Gorgan, Ali-Abad KenaarShahr village $\left(36.90^{\circ} \mathrm{N}, 54.52^{\circ} \mathrm{E}, 97 \mathrm{~m}\right.$ a.s.l.), 12.vii.2020, leg.: V. Rahiminejhad.

Remarks. This is a first record of $P$. dudichi and the tenth Pediculaster representative for Iranian mite fauna (Seyedein et al., 2021).

\section{Family Neopygmephoridae Cross, 1965}

\section{Genus Allopygmephorus Cross, 1965}

Type species: Pygmephorus matthesi Krczal, 1959, by original designation.

\section{Allopygmephorus heterodactylus Mahunka, 1973}

World distribution. Ghana - collected from undetermined beetle (Mahunka, 1973).

Material examined. 2우, Iran, Golestan province, Gorgan, Ali-Abad Kenaar-Shahr village $\left(36.90^{\circ} \mathrm{N}\right.$, $54.52^{\circ} \mathrm{E}, 97 \mathrm{~m}$ a.s.l.), associated with Cercyon sp. (Col.: Hydrophyllidae), captured by a light trap, 30.vii.2020, leg.: V. Rahiminejhad.

Remarks. This is the first record of phoretic association between this mite and the host beetle of the genus Cercyon Leach, 1817. Also, this species is recorded for the first time from Asia.

\section{Allopygmephorus matthesi Kraczal, 1959}

World distribution. Germany - associated with several beetles, Berosus luridus L., Coelostoma orbiculare F., Enochrus quadripunctatus Herbst, Helochares griseus F., H. lividus Forster, Hydrobius fuscipes L., Hydrophilus caraboides F., Philydrus melanocephalus F. (Hydrophilidae), Heterocerus marginatus F. (Heteroceridae), Dryops auriculalns Geoffroy (Dryopidae). Tanzania-collected from undetermined beetle (Kraczal, 1959; Mahunka, 1973).

Material examined. More than 45우, Iran, Colestan province, Gorgan, Sorkhan-Kkalateh village $\left(36.99^{\circ} \mathrm{N}, 54.56^{\circ} \mathrm{E}, 105 \mathrm{~m}\right.$ a.s.l.), associated with Xyleborus sp. (Col.: Curculionidae: Scolytinae), 8.vi.2020, leg.: V. Rahiminejhad.

Remarks. This is the first record of phoretic association between the mite and the host genus Xyleborus. Also, this species is recorded for the first time from Asia.

\section{Allopygmephorus orientalis Mahunka and Mahunka, 1988}

World distribution. Malaysia - extracted from soil samples (Mahunka \& Mahunka, 1988). 
Material examined. 2 우, Iran, Golestan province, Gorgan, Nodijeh village $\left(36.49^{\circ} \mathrm{N}, 54.16^{\circ} \mathrm{E}, 28 \mathrm{~m}\right.$ a.s.1.), extracted from a soil sample in the vicinity of dry rice cultivation, 21.vi.2020; 19, Gorban, Sorkhan-Kalateh village $\left(36.99^{\circ} \mathrm{N}, 54.56^{\circ} \mathrm{E}, 105 \mathrm{~m}\right.$ a.s.l.), 27.vii.2020, leg.: V. Rahiminejhad.

Remarks. The species is a new record for mite fauna of Iran.

Family Microdispidae Cross, 1965

Genus Premicrodispus Cross, 1965

Type species: Microdispus (Premicrodispus) chandleri Cross, 1965, by original designation.

Three subgenera, Premicrodispus Cross, 1965, Premicrodispulus Khaustov \& Chydyrov, 2010,

Premicrodispoides Khaustov \& Maslov, 2013, and about 31 species constitute the cosmopolitan genus, Premicrodispus (Khaustov \& Minor, 2020). Recently, Iranian Premicrodispus mites have been reviewed and a new species described in association with Lucanus ibericus Motschulsky, 1845 (Col.: Lucanidae) (Seyedein et al., 2020)

\section{Premicrodispus stenops (Mahunka, 1969)}

World distribution. Previously, P. stenops was extracted from Mongolian soil samples (Mahunka, 1969).

Material examined. 2oㅇ, Iran, Golestan province, Sorkhan-Kalateh village $\left(36.99^{\circ} \mathrm{N}, 54.56^{\circ} \mathrm{E}, 105 \mathrm{~m}\right.$ a.s.l.), extracted from a soil sample under Poplar trees (Populus sp.) in vicinity of dry rice cultivation, 6.viii.2020, leg.: V. Rahiminejhad.

Remarks. The species is a new record for mite fauna of Iran.

\section{Genus Paramicrodispus Khaustov, 2009}

Type species: Brennandania crenulata Savulkina, 1978

\section{Paramicrodispus Crenulatus (Savulkina, 1978)}

World distribution. Bulgaria - in the nest of a small mammal (Savulkina, 1978). Ukraine (Crimea) beneath elytra of a carabid beetle Pterostichus niger (Schaller, 1783), in a rotten log of Fagus orientalis (Khaustov, 2009). Iran-in association with Lucanus ibericus Motschulsky, 1845 (Col.: Lucanidae) (Hajiqanbar et al., 2012).

Material examined. 8우 , Iran, Golestan province, Gorgan, Sorkhan-Kalateh village $\left(36.99^{\circ} \mathrm{N}, 54.56^{\circ} \mathrm{E}\right.$, $105 \mathrm{~m}$ a.s.l.), extracted from a soil sample in vicinity of dry rice cultivation, 14.viii.2020, leg.: V. Rahiminejhad.

Remarks. The species is recorded for the first time from soil.

Family Scutacaridae Oudemans, 1916

Genus Scutacarus Gros, 1845

Type species: Scutacarus femoris Gros, 1845

\section{Scutacarus sphaeroideus Karafiati, 1959}

World distribution. This species has world-wide distribution and inhabits soils shorelines (Khaustov, 2008) and has been found to be phoretic on ants, beetles (Staphylinidae, Heteroceridae) and small mammals (Cricetidae, Muridae) (Baumann \& Ferragut, 2018). This species has been collected several 
times in Iran from soil samples and associated with hydrophilid beetles (Col:: Hydrophilidae) and Dryops sp. (Col.: Dryopidae) (Hajiqanbar, 2008; Tajodin, 2013; Seyedein et al., 2020).

Material examined. 50우, Iran, Golestan province, Gorgan, Nodijeh village $\left(36.49^{\circ} \mathrm{N}, 54.16^{\circ} \mathrm{E}, 28 \mathrm{~m}\right.$ a.s.1.), 2 우, Sorkhan-Kalateh village $\left(36.99^{\circ} \mathrm{N}, 54.56^{\circ} \mathrm{E}, 105 \mathrm{~m}\right.$ a.s.l.) and Ali-Abad Kenaar-Shahr village $\left(36.90^{\circ} \mathrm{N}, 54.52^{\circ} \mathrm{E}, 97 \mathrm{~m}\right.$ a.s.l.), extracted from soil samples, vi-viii.2019, leg.: V. Rahiminejad..

Key to the genera and species of Heterostigmata recorded from dry rice cultivation in Gorgan, northern Iran

1. Tarsus I with paired claws; trochanters of legs I, II, IV, and usually III lacking setae; females lacking the stigmata and associated tracheae (Superfamily Dolichocyboidea; Family Dolichocybidae).

Dolichomotes crossi Rack, 1973

- Tarsus I without/with a single claw; trochanters of legs I-IV usually with a seta each; females with a pair of stigmata and associated tracheae anterolaterally on prodorsum (Superfamily Pygmephoridae). .................. 2

2. Prodorsum of females not covered posteriorly by tergite $C$ and usually with 3 pairs of setiform setae $\left(v_{1}\right.$ and usually $v_{2}$ present); coxisternal plates I-II together with 4-6 pairs of setae; femur I usually with 4 setae (Family Pygmephoridae).

Pediculaster dudichi Mahunka, 1970

- Prodorsum of females usually covered to some extent by tergite $C$ and with 1-2 pairs of setiform setae $\left(v_{1}\right.$ and sometimes $v_{2}$ absent); coxisternal plates I-II together with maximum of 4 pairs of setae. Femur I with 3 setae. 3

3. Prodorsum with 1 pairs of setiform setae (Family Microdispidae) ………......................................................... 4

- Prodorsum usually with 2 pairs of setiform setae. 5

4. Posterior margin of posterior sternal plate with three large lobes (tripartite); eupathidium $f^{\prime}$ present on tibiotarsus I (Genus Premicrodispus) ..... P. stenops (Mahunka, 1969)

- Posterior margin of posterior sternal plate without lobe; eupathidium $f t^{\prime}$ absent on tibiotarsus I (Genus Paramicrodispus). P. crenulatus (Savulkina, 1978)

5. Tergite $C$ expansive, entirely covering prodorsum, forming a roof over gnathosoma; setiform setae of prodorsum usually inconspicuous and often difficult to discern. Distance between insertions of legs II-III usually similar to that between legs III-IV (Family Scutacaridae).

Scutacarus sphaeroideus Karafiati, 1959

- Tergite C not covering entire prodorsum and gnathosoma; setiform setae of prodorsum usually often conspicuous; distance between insertions of legs II-III usually two times longer than the distance between legs III-IV (Family Neopygmephoridae; Genus Allopygmephorus).

6. Claws on tarsus II and III symmetric.

A. matthesi Kraczal, 1959

- Claws on tarsus II and III asymmetric.

7. Seta $f$ more than three times longer than $e$.

A. orientalis Mahunka \& Mahunka, 1988

- Seta $f$ less than two and half times longer than $e$. A. heterodactylus Mahunka, 1973

\section{DISCUSSION}

Considering the six new recorded species in the course of present study, the number of Dolichomotes, Pediculaster, Allopygmephorus and Premicrodispus genera representatives of Iran reached to two, six, six and 13 species, respectively (Table 1). Golestan province, compared to the other regions of Iran, have had a conspicuous role introducing new records and species of Heterostigmatina. Besides more than 40 new records for Iranian heterostigmatic mite fauna, three genera and 20 species have been described from Golestan province, so far (Rahiminejad et al., 2020a, 2020b; Rahiminejad \& Hajiqanbar, 2020; Seyedein et al., 2020, 2021). It is recommendable that further research on these mites in various ecosystems gives a better understanding of various aspect of their life. 
Table 1. All Iranian species of the genera Dolichomotes, Pediculaster, Allopygmephorus and Premicrodispus.

\begin{tabular}{|c|c|}
\hline Genera \& species & References \\
\hline Dolichomotes Smiley, 1967 & Mortazavi et al., 2015 \\
\hline $\begin{array}{l}\text { D. sinuspersicus Mortazavi \& Hajiqanbar, } 2015 \\
\text { D. crossi Rack, } 1973\end{array}$ & Present study \\
\hline Pediculaster Vitzthum, 1931 & Filekesh et al., 2014 \\
\hline P. manicatus (Berlese, 1904) & Rahiminejad \& Hajiqanbar, 2020 \\
\hline P. pseudomanicatus Camerik, 2001 & Seyedein et al., 2021 \\
\hline P. mesembrinae (Canestrini, 1881) & Present study \\
\hline \multicolumn{2}{|l|}{ P. camerikae Khaustov, 2008} \\
\hline \multicolumn{2}{|l|}{ P. absentia Rahiminejad \& Seyedein, 2021} \\
\hline \multicolumn{2}{|l|}{ P. dudichi Mahunka, 1970} \\
\hline Allopygmephorus Cross, 1965 & Khaustov \& Hajiqanbar, 2006 \\
\hline A. persicus Khaustov \& Hajiqanbar, 2006 & Navabi et al., 2018 \\
\hline A. spinisetus Khaustov \& Sazhnev, 2016 & Present study \\
\hline \multicolumn{2}{|l|}{ A. punctatus Khaustov \& Sazhnev, 2016} \\
\hline \multicolumn{2}{|l|}{ A. heterodactylus Mahunka, 1973} \\
\hline \multicolumn{2}{|l|}{ A. matthesi Kraczal, 1959} \\
\hline \multicolumn{2}{|l|}{ A. orientalis Mahunka \& Mahunka, 1988} \\
\hline Premicrodispus Cross, 1965 & Hajiqanbar \& Sobhi, 2018 \\
\hline P. acuitisetus Khaustov, 2009 & Rahiminejad et al., 2020a, 2020b \\
\hline P. rackae Khaustov, 2006 & Seyedein et al., 2020 \\
\hline P. turkmenus Badoodam \& Hajiqanbar, 2015 & Present study \\
\hline \multicolumn{2}{|l|}{ P. spinosus Hosseininaveh \& Hajiqanbar, 2015} \\
\hline \multicolumn{2}{|l|}{ P. paramaevi Hosseininaveh \& Hajiqanbar, 2015} \\
\hline \multicolumn{2}{|l|}{ P. longicaudus Khaustov, 2006} \\
\hline \multicolumn{2}{|l|}{ P. akermanae (Sevastianov \& Al Douri, 1988) } \\
\hline \multicolumn{2}{|l|}{ P. krczali Khaustov, 2006} \\
\hline \multicolumn{2}{|l|}{ P. lineatus (Mahunka, 1986) } \\
\hline \multicolumn{2}{|l|}{ P. brevisetus Khaustov, 2006} \\
\hline \multicolumn{2}{|l|}{ P. gorganiensis Rahiminejad \& Seyedein, 2020} \\
\hline \multicolumn{2}{|l|}{ P. montanus Khaustov, 2006} \\
\hline P. stenops (Mahunka, 1969) & \\
\hline
\end{tabular}

\section{AUTHOR'S CONTRIBUTION}

The authors confirm contribution in the paper as follows: V.R.: Collected, sorted and prepared the specimens and prepared the manuscript. M.Y.: Edited the first version of the manuscript. S.Z.: Collected the specimens. All authors read and approved the final contents of the manuscript.

\section{FUNDING}

This work was financialy support by the Gorgan University of Agricultural Sciences and Natural Resources, Gorgan (Grant No. 98-412-34)

\section{AVAILABILITY OF DATA AND MATERIAL}

Not applicable. 


\section{ETHICS APPROVAL AND CONSENT TO PARTICIPATE}

Not applicable.

\section{CONSENT FOR PUBLICATION}

Not applicable.

\section{CONFLICT OF INTERESTS}

The authors declare that there is no conflict of interest regarding the publication of this paper.

\section{ACKNOWLEDGMENTS}

The authors wish to thank the Vice Presidency for Research and Technology, Gorgan University of Agricultural Sciences and Natural Resources for financial support of this research. This paper is dedicated to the memory of Dr. Hamidreza Hajiqanbar who sadly passed away on 14 October 2021. He was one of the most dynamic scientists who works on the taxonomic and systematics of heterostigmatic mites.

\section{REFERENCES}

Baumann, J. \& Ferragut, F. (2018) New species and reports of scutacarid mites from Andalusia, Spain, (Heterostigmatina, Scutacaridae). Systematic \& Applied Acarology, 23 (1), 145-160. https:/ / doi.org/10.11158/ saa.23.1.12

Filekesh, M., Hajiqanbar, H. \& Jabaleh, I. (2014) New records of three species of the superfamily Pygmephoroidea (Acari: Heterostigmata) from Asia. Persian Journal of Acarology, 3, 277-283. https:// doi.org/10.22073/ pja.v3i4.10170

Ghorbaniminaei, L., Zakerinia, M., Rezaeias, A. \& Mirkarimi, H.R. (2019) The effect of sub-irrigation on rice yield with refined municipal wastewater. Journal of Water and Soil, 33 (6), 885-896.

Gwiazdowicz, D.J. (2021) Biodiversity of mites. Diversity, 13, 80. https:/ / doi.org/10.3390/d13020080

Hajiqanbar, H. (2008) Heterostigmatic mites (Acari: Heterostigmata) associated with Coleoptera and Hymenoptera in some regions of Razavi and north Khorasan province (Unpublished PhD dissertation), Department of Entomology, Faculty of Agriculture, Tarbiat Modares University, Tehran, Iran.

Hajiqanbar, H. \& Sobhi, M. (2018) New records of the microdispid mites (Acari: Heterostigmata: Microdispidae) associated with ants with a review of the family in Iran. Persian Journal of Acarology, 7 (2), 105-113.

Hajiqanbar, H., Rahiminejad, V. \& Fathipour, Y. (2012) New insect host records for mites of the family Microdispidae (Acari: Heterostigmatina), with description of a new species of the genus Paramicrodispus. Entomological Science, 15 (3), 309-313. https:/ / doi.org/10.1111/j.1479-8298.2012.00515.x

Jaiswal, D.K., Singh, J., Singh, D.K. \& Singh, N.K. (2016) Comparative evaluation of panicle rice mite infestation in different varieties of paddy in Chandauli and Varanasi district (Purvanchal). Advances in Life Science, 5 (5), 1822-1825.

Kaliszewski, M., Athias-Binche, F. \& Lindquist, E.E. (1995) Parasitism and parasitoidism in Tarsonemina (Acari: Heterostigmata) and evolutionary considerations. Advances in Parasitology, 35, 335-67. https://doi.org/10.1016/S0065-308X(08)60074-3

Kayal, S., Karmakar, K. \& Moraes, G.J. (2021) Sources of infestation of the rice sheath mite, Steneotarsonemus spinki Smiley (Acari: Tarsonemidae), in West Bengal, India. International Journal of Pest Management, in press, 1-7. https:/ / doi.org/10.1080/09670874.2021.1973691

Khaustov, A.A. (2004) Mites of the family Neopygmephoridae Cross, 1965 stat. n. and their position in Heterostigmata. In: Balashov, Y.S. (Ed.), VIII Russian Acarological Conference, St.-Petersburg. Zoological Institute of RAS, St.Petersburg, p. 137. [in Russian].

Khaustov, A.A. (2008) Mites of the family Scutacaridae of Eastern Palaearctic. Akademperiodyka, Kiev. 291 pp.

Khaustov, A.A. (2009) A new genus and three new species of the mite family Microdispidae (Acari: Heterostigmata) from Crimea. Acarina, 17, 65-73.

Khaustov, A.A. \& Hajiqanbar, H. (2006) Redefinition of the genus Allopygmephorus (Acari: Heterostigmata: Neopygmephoridae), with description of a new species from Iran. Acarina, 14, 191-194. 
Khaustov, A.A. \& Minor, M.A. (2020) New species of Microdispidae (Acari: Heterostigmata) from alpine New Zealand. Zootaxa, 4750 (4), 477-498. https://doi.org/10.11646/zootaxa.4750.4.2

Krczal, H. (1959) Systematic und Okologie der Pyemoten. In: Stammer, H.J. (ed.) Beitrag zur Systematic und Okologie mitteleuropaischer Acarina. Geest und Portig, Leipzig, pp. 385-625.

Mahunka, S. (1969) Pyemotidae and Scutacaridae IV. Ergebnisse der zoologischen Forschungen von Dr. Z. Kaszab in der Mongolei (Acari). Reichenbachia, 12, 83-112.

Mahunka, S. (1970) Considerations on the systematics of the Tarsonemina and the description of new European taxa (Acari: Trombidiformes). Acta Zoologica Academiae Scientiarum Hungaricae, 16, 137-174.

Mahunka, S. (1973) Auf Insecten lebende Milben (Acari: Acarida, Tarsonemida) aus Afrika. II. Acta Zoologica Hungaricae, 19, 289-337.

Mahunka, S., \& Mahunka-Papp, L. (1988) Neue und interessante Milben aus dem Genfer Museum. LIX. Hauseripes hungarorum gen. ח., sp. n. and some other new Tarsonemina (Acari) from Sabah (East Malaysia). Revue Suisse de Zoologie, 95, 581-594. https://doi.org/10.5962/bhl.part.79673

Mortazavi, A., Hajiqanbar, H. \& Kamali, K. (2015) A new species of the family Dolichocybidae Mahunka, 1970 (Acari: Heterostigmata) associated with Sinoxylon pugnax Lesne (Insecta: Coleoptera: Bostrichidae) from Iran. Systematic \& Applied Acarology, 20 (4), 441-448. https:/ / doi.org/10.11158/saa.20.4.9

Navabi, A., Hajiqanbar, H. \& Mortazavi, A. (2018) New records of the genus Allopygmephorus (Acari: Neopygmephoridae) with a list of the species of the family Neopygmephoridae in Iran. Persian Journal of Acarology, 7 (4), 315-322. https://doi.org/10.22073/pja.v7i4.40314

Okabe, K., Masuya, H. \& Kanzaki, N. (2012) Regional collapse of symbiotic specificity between lucanid beetles and canestriniid mites. Naturwissenschaften, 99, 959-965. https:/ / doi.org/10.1007/s00114-012-0979-0

Rack, G. (1973) Dolichomotes crossi sp. n. from California and a key for the identification of the family Dolichocybidae (Acarina, Pyemotoidea). Acarologia, 15 (2), 337-341.

Rahiminejad, V. \& Hajiqanbar, H. (2020) New records of mites of the Heterostigmata (Acari: Prostigmata) associated with insects from Golestan province, northern Iran. Persian Journal of Acarology, 9 (3), 233-242.

Rahiminejad, V., Hajiqanbar, H. \& Talebi, A.A. (2020a) An alpha diversity survey of heterostigmatic mites (Trombidiformes, Prostigmata) phoretic on scarabaeoid beetles in Hyrcani forest, northern Iran. Systematic $\mathcal{E}$ Applied Acarology, 25 (11), 2033-2046. https:/ / doi.org/10.11158/saa.25.11.9

Rahiminejad, V., Seyedein, S. \& Nadimi, A. (2020b) New records of soil dwelling mites of the superfamily Pygmephoroidea (Acari: Heterostimatina) from northern Iran. Journal of Insect Biodiversity and Systematics, 6 (3), 307-315.

Razzaghi, M.H., Kiani, A. \& Abyar, N.M. (2020) Rice transplanting and direct seeding cultivation, technical and economic solution for rice production in Golestan province (on Farm). Water Management in Agriculture, 7 (1), 33-44.

Savulkina, M.M. (1978) Neue Pygmephoriden-Arten (Trombidiformes, Pygmephoridae) aus Nagernestern von Bulgarien und der Sowjetunion. Parasitologica Hungarica, 11, 127-140.

Seyedein, S., Rahiminejad, V. \& Nadimi, A. (2020) Two new species of microdispid mites (Acari: Heterostigmata: Pygmephoroidea) associated with Lucanus ibericus (Coleoptera: Lucanidae). Acarologia, 60 (3), 595-606. https://doi.org/10.24349/acarologia/20204388

Seyedein, S., Rahiminejad, V. \& Nadimi, A. (2021) New records of the genus Pediculaster Vitzthum, 1931 (Acari: Heterostigmata: Pygmephoridae) with description of a remarkable new species, associated with Helina sp. (Diptera: Muscidae) from Iran. Biologia, 76, 1509-1516. https:// doi.org/10.2478/s11756-020-00657-x

Tajodin, M. (2013) Heterostigmatic Mites (Acari: Heterostigmatina) associated with insects in west of Isfahan province, Iran (Unpublished M.Sc. thesis), Department of Plant Protection, Faculty of Agriculture, Tarbiat Modares University.

Walter, D.E., Lindquist, E.E., Smith, I.M., Cook, D.R., \& Krantz, G.W. (2009) Order Trombidiformes. In: Krantz, G.W. \& Walter, D.E. (eds) A Manual of Acarology. Texas, Texas Tach Universiy Perss, USA, pp. 233-420.

Zhang, Z.Q., Fan, Q.H., Pešić, V., Smith, H., Bochkov, A.V., Khaustov, A.A., Baker, A., Wohltmann, A., Wen, T., Amrine, J.W., Beron, P., Lin, J., Gabrys, G. \& Husband, R. (2011) Order Trombidiformes Reuter, 1909. In: Zhang Z.Q. (ed.) Animal biodiversity: An outline of higherlevel classification and survey of taxonomic richness, Zootaxa, 3148, 129-138. https:// doi.org/10.11646/zootaxa.3148.1.24 
كزارشهاى جديد از كنههاى هترواستيعما (Acari: Heterostimatina) در برنج خشكه كارى در گرَان، شمال

وحيد رحيمىنزاد"، محسن يزدانيان و صفيه زيتونلى

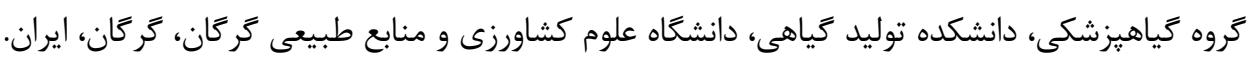

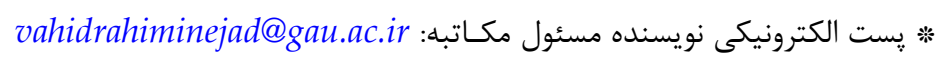

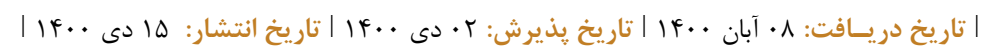

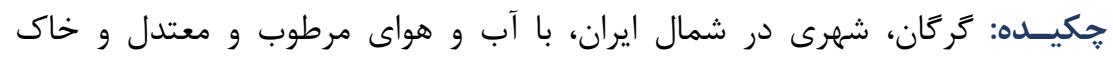

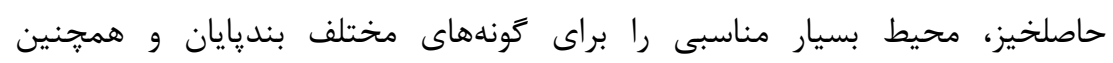

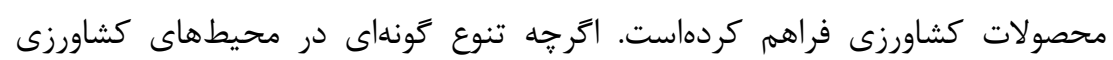

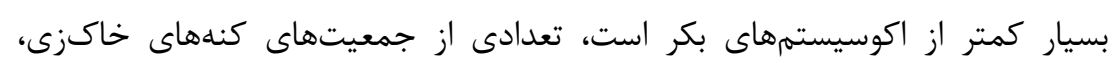

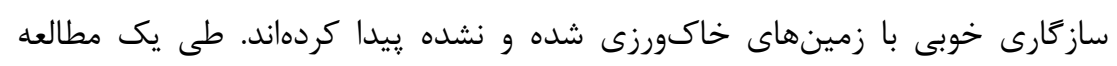
فونستيك برروى كنهاى هترواستيخما (Acari: Prostigmata: Heterostigmatina)

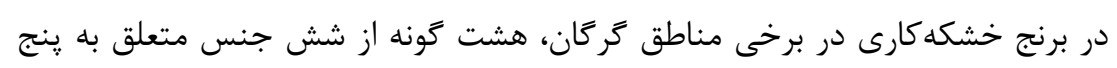

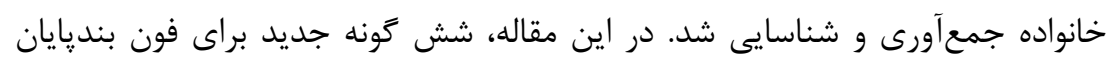

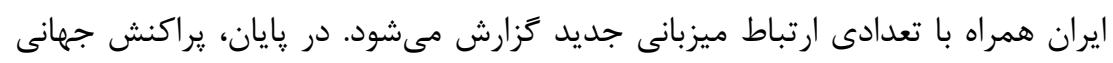

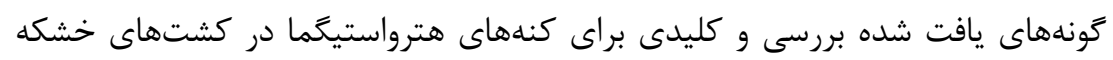
برنج در شهر گركان ارايه شد.

وازَّـان كليدى: كنه، حشره، خاك، محصولات كشاورزى، همسفرى، ايران 